\title{
Nye retningslinjer for antitrombotisk behandling og tromboseprofylakse
}

\author{
Nye retningslinjer med 250 anbefalinger for antitrombotisk behandling og tromboseprofylakse er nå tilgjen- \\ gelig på nett. Retningslinjene fra Norsk selskap for trombose og hemostase imøtekommer nye standarder \\ for troverdige retningslinjer og benytter seg av innovative teknologiske løsninger.
}

Forebygging og behandling av venøs og arteriell trombose stiller leger overfor utfordringer i klinisk praksis, ikke minst på grunn av rask kunnskapsutvikling og nye behandlingsalternativer. Fordelene ved behandling (reduksjon i tromboser) må vurderes mot ulempene (blødningsrisiko, praktiske konsekvenser). For å kunne balansere vurderingen trenger man tilgang til oppdatert og gyldig forskningsbasert kunnskap.

\section{Ny generasjon retningslinjer}

De nye anbefalingene (1) er basert på internasjonale retningslinjer publisert i februar 2012 (2). Vi har oppdatert, restrukturert og endret anbefalingene for å tilpasse dem til bruk i Norge. Arbeidet er utført av en gruppe leger utnevnt av de fagmedisinske foreningene i Legeforeningen, koordinert av Norsk selskap for trombose og hemostase. Retningslinjene er relevant for de fleste leger i primær- og spesialisthelsetjenesten. Det gis anbefalinger for behandling av dyp venetrombose og lungeembolisme, atrieflimmer, kardiovaskulær sykdom, profylakse ved kirurgiske, indremedisinske og ortopediske tilstander, trombose i graviditet samt perioperativ og praktisk håndtering av legemidler for antikoagulasjon. Vi har innlemmet praktiske råd vedrørende de nye antikoagulasjonsmidlene, utviklet av Helsedirektoratet og Legemiddelverket (3).
Vi har benyttet oss av et nytt rammeverk ved utforming av retningslinjene, utført gjennom forsknings- og innovasjonsprogrammet MAGIC (MAking GRADE the Irresistible Choice) (4). Retningslinjene er tilgjengelig på nett, brett og smarttelefoner, og slik vi ser det, i et mer brukervennlig format enn andre retningslinjer. I nær fremtid vil de kunne integreres i elektronisk pasientjournal knyttet til pasientdata som ledd i kliniske beslutningsstøttesystemer og arbeid med kvalitetsforbedring, og brukes i pasientkonsultasjoner gjennom verktøy som gir informasjon om fordeler og ulemper ved behandlingsvalg.

\section{GRADE}

Systemet Grading of Recommendations Assessment, Development and Evaluation (GRADE) tilrettelegger for en systematisk og transparent prosess for utvikling av anbefalinger (5).

Styrken på anbefalingen reflekterer hvor sikker retningslinjegruppen er på at fordelene ved en behandling veier opp for ulempene. En sterk anbefaling innebærer således at fordelene klart veier opp for ulempene og nær sagt alle pasienter vil ønske den anbefalte intervensjonen. Ved svake anbefalinger er denne balansen noe mer usikker eller det er lav kvalitet på dokumentasjonen. Anbefalingen vil frem-

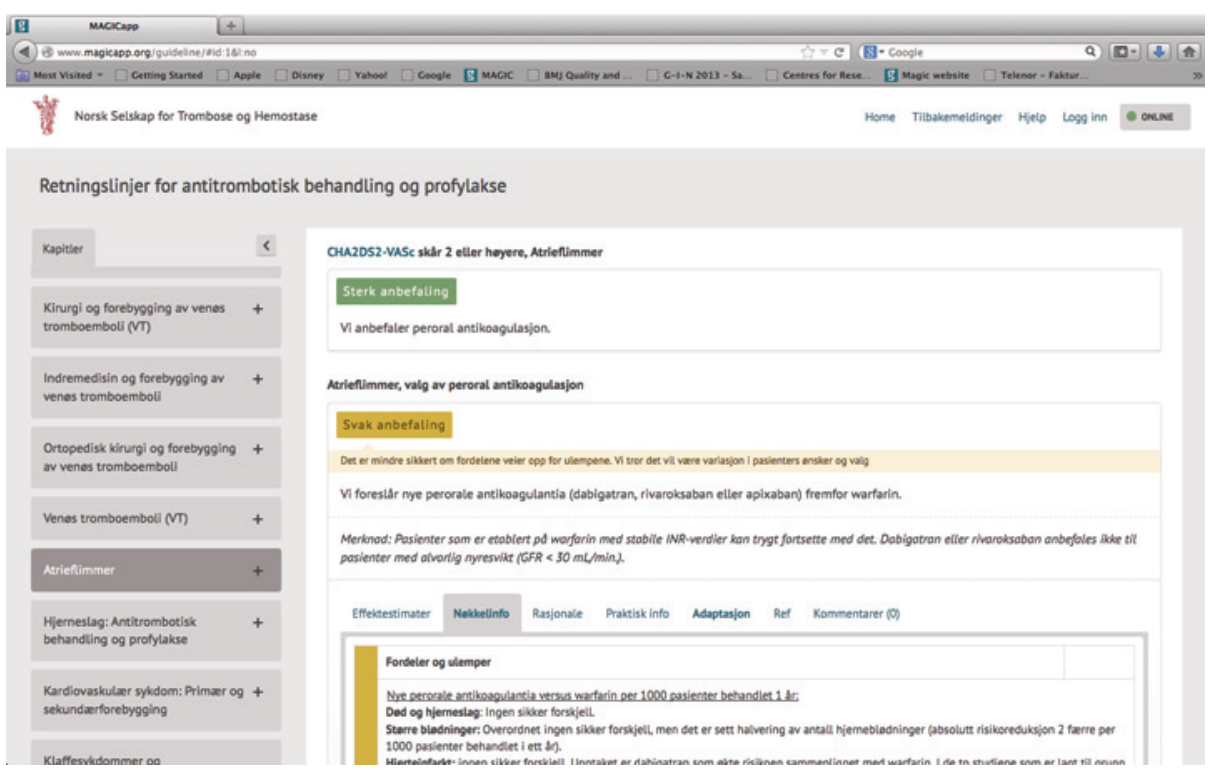

deles gjelde de fleste pasientene, men det er større mulighet for individuelle preferanser.

De fleste anbefalingene i retningslinjene er svake, hvilket gjør det desto viktigere å gjøre kunnskapsgrunnlaget tilgjengelig for å hjelpe klinikere å bruke anbefalingene balansert overfor enkeltpasienter.

Et typisk eksempel er sekundærprofylakse etter et iskemisk hjerneslag. Her gir retningslinjene en sterk anbefaling for behandling med platehemmende medikamenter. Derimot gis det en svak anbefaling i favør av klopidogrel eller kombinasjonen acetylsalisylsyre og dipyridamol fremfor monoterapi med acetylsalisylsyre. Det betyr at det ses klare fordeler ved platehemmende behandling, men det er mer usikkert om et av behandlingsregimene er bedre enn et annet. Dette åpner for at pasienter og klinikere i større grad sammen kan velge hvilket regime pasienten bør bruke.

\section{Veien videre}

Vi håper leger vil kunne nyttiggjøre seg retningslinjene i klinisk praksis og imøteser tilbakemeldinger slik at vi kontinuerlig kan forbedre både faglig innhold og brukervennlighet.

\section{Annette Kristiansen \\ annettekrist@gmail.com \\ Linn Brandt \\ Eivind Berge \\ Anders Erik Astrup Dahm \\ Sigrun Halvorsen \\ Per Morten Sandset \\ Per Olav Vandvik}

Annette Kristiansen (f. 1979) er ph.d.-stipendiat ved Sykehuset Innlandet og lege i spesialisering i indremedisin Diakonhjemmet Sykehus. Forfatter har fylt ut ICMJE-skjemaet og oppgir følgende interessekonflikter: Hun er med i MAGIC som kan søke patent.

Linn Brandt (f. 1980) er lege i spesialisering i indremedisin, Diakonhjemmet Sykehus, ph.d. stipendiat ved Sykehuset Innlandet. Forfatter har fylt ut ICMJE-skjemaet og oppgir følgende interessekonflikter: Hun har mottatt støtte fra Legeforeningen og Innovasjon Norge.

Eivind Berge (f. 1964) er spesialist i indremedisin og i hjertesykdommer og driver klinisk hjerneslagforskning. Forfatter har fylt ut ICMJE-skjemaet og oppgir ingen interessekonflikter. 
Anders Erik Astrup Dahm (f. 1968) er dr.med. og lege i spesialisering ved Avdeling for blodsykdommer, Oslo universitetssykehus.

Forfatter har fylt ut ICMJE-skjemaet og oppgir følgende interessekonflikter: Han har mottatt forelesningshonorar fra Pfizer.

Sigrun Halvorsen (f. 1958) er spesialist i hjertesykdommer, konstituert avdelingsleder ved Hjertemedisinsk avdeling, Oslo universitetssykehus, Ullevål, og styremedlem i ESC Working Group of Thrombosis.

Forfatter har fylt ut ICMJE-skjemaet og oppgir følgende interessekonflikter: Hun har mottatt forelesningshonorar fra EliLilly, Pfizer, Boehringer Ingelheim, AstraZeneca, Bayer og Bristol-Myers Squibb.

Per Morten Sandset (f. 1956) er spesialist i indremedisin og i blodsykdommer og er forskningsleder ved Oslo universitetssykehus og professor ved Universitetet i Oslo.

Forfatter har fylt ut ICMJE-skjemaet og oppgir følgende interessekonflikter: Han har mottatt støtte som undersøker og koordinator for DVT/ PE-studiene (Amplify and Amplify Extention) fra Daichi-Sankyo og Pfizer.

Per Olav Vandvik (f. 1968) er postdoktorstipendiat og overlege ved Sykehuset Innlandet, Gjøvik. Forfatter har fylt ut ICMJE-skjemaet og oppgir følgende interessekonflikter: Han leder MAGICforskningsprogrammet og den uavhengige ideelle foreningen MAGIC som eier og har copyright til MAGICapp.

\section{Litteratur}

1. MagicApp. www.nsth.no (22.2.2014)

2. Guyatt G, Akl E, Crowther $M$ et al. Executive summary: Antithrombotic Therapy and Prevention of Thrombosis, 9th ed: American College of Chest Physicians Evidence-Based Clinical Practice Guidelines. Chest 2012; 141(suppl 2): 7S-47S.

3. Informasjon om warfarin og de nye perorale antikoagulasjonsmidlene dabigatran, rivaroksaban og apixaban. IS-2050. Oslo: Helsedirektoratet, 2013.

4. Vandvik PO, Brandt L, Alonso-Coello P et al. Creating clinical practice guidelines we can trust, use, and share: a new era is imminent. Chest 2013; 144:381-9.

5. Goldet G, Howick J. Understanding GRADE: an introduction. J Evid Based Med 2013; 6: 50-4.

Mottatt 6.12. 2013, første revisjon innsendt 19.2. 2014, godkjent 22.2. 2014. Redaktør: Kari Tveito.

Publisert først på nett. 